\title{
A case of scrotal swelling mimicking testicular torsion preceding Henoch-Schönlein vasculitis
}

\author{
Akgun C \\ Yuzuncu Yil University, School of Medicine, Department of Pediatrics, Division of Pediatric Nephrology, Turkey. \\ cihangirakgun@gmail.com
}

\begin{abstract}
Henoch-Schönlein purpura, is one of the most common types of multisystemic vasculitis seen in childhood. The major clinical manifestations are cutaneous purpura, arthritis, abdominal pain, gastrointestinal bleeding, and nephritis. Isolated central nervous system vasculitis, seizures, coma and hemorrhage, Guillan-Barré syndrome, ataxia and central and peripheral neuropathy, ocular involvement, orchitis, epididymitis or testicular torsion are medical or surgical complications. In this study, we report a 7-year-old boy with scrotal swelling mimicking testicular torsion with ultrasonographic and clinical findings that the typical clinical features of Henoch-Schönlein purpura including rashes and arthritis were developed after one week of surgery (Ref. 15). Full Text in PDF www.elis.sk.

Key words: scrotal swelling, mimicking testicular torsion, Henoch-Schönlein vasculitis, Guillan-Barré syndrome, arthritis.
\end{abstract}

Henoch-Schönlein purpura (HSP) is one of the most common types of multisystemic vasculitis seen in childhood and characterized by non-thrombocytopenic, non-blanching purpura, arthritis, abdominal pain, and renal involvement (1). The epidemiology of HSP is obscure and in the literature there are different values of incidence of this disease. An incidence of 13.5 cases per 100,000 children per year was observed by Stewart M. et al. whereas $0.2-10$ cases per 100,000 were reported by Farley et al $(2,3)$. Although the major clinical manifestations are cutaneous purpura, arthritis, abdominal pain, gastrointestinal bleeding, and nephritis, other manifestations include an isolated central nervous system vasculitis, seizures, coma and hemorrhage, Guillan-Barré syndrome, ataxia and central and peripheral neuropathy, ocular involvement, orchitis, epididymitis or testicular torsion are other medical or surgical conditions that can be seen with HSP (4). The present report details a case of a young Turkish boy with scrotal swelling mimicking testicular torsion with ultrasonographic findings and with the typical clinical features of HSP developed one week after the surgery.

\section{Case report}

A 7-year-old boy was brought to emergency department with complaints of scrotal swelling and pain lasting 1 day. Except a history of brucellosis 2 years ago, the personal and family his-

Yuzuncu Yil University, School of Medicine, Department of Pediatrics, Division of Pediatric Nephrology, Turkey

Address for correspondence: C. Akgun, MD, Yuzuncu Yil University, School of Medicine, Department of Pediatrics, Division of Pediatric Nephrology, 65200, Van, Turkey.

Phone: +90.533.6513323, Fax: +90.432.2150479 tories were unremarkable. Moreover, recent history of infectious disease or trauma was not described. At the time of admission, there were left scrotal edema and testicular pain and he had no rash in any part of the body. The laboratory investigations revealed hemoglobin $13.1 \mathrm{~g} / \mathrm{dl}$, white blood cell count $13000 / \mu \mathrm{L}$ and platelet count $462,000 / \mu \mathrm{L}$. Serum electrolytes, liver enzymes, blood coagulation tests, antinuclear antibody, rheumatoid factor, antistreptolysin $\mathrm{O}$, serum IgA level and urinalysis were within normal levels. On ultrasonographic examination decreased blood flow and enlarged testis were seen. Surgical exploration revealed a hematocele, with bloody fluid accumulation mainly in the tunica vaginalis testis and an edematous, hyperemic testis and epydidymis without torsion of both of them. Edema of testis and epydidymis resolved after surgery. The patient was discharged without any complication on the 3rd day of hospitalization. 4 days after the discharge he was again brought to emergency department with complaints of leg rashes and leg pain. Physical examination revealed blood pressure of 110/70 $\mathrm{mmHg}$, bilateral symmetric palpable purpura on the lower extremities and buttocks and swelling on the left ankle joint. Skin biopsy was done for differential diagnosis and on skin punches biopsy, capillaries and venules of the dermis were affected by a leukocytoclastic vasculitis with vessel wall necrosis and perivascular accumulation of polymorphonuclear leukocytes and mononuclear cells. Immunofluorescence microscopy was positive for IgA. There were no renal or other systemic involvement findings. Antihistaminic and non-steroid anti-inflammatory drugs were initiated for pruritus and arthritis, respectively, with the diagnosis of HSP. Left ankle joint arthritis relieved on 3rd day and his rashes resolved in three weeks. He is now in the 6th month of follow-up and he was fully recovered without any relapse and renal or systemic involvement of HSP. 


\section{Discussion}

Acute scrotum is a condition with an acute painful swelling of the scrotum or its contents accompanied by local signs and general symptoms (5). Vasculitic involvement of the systems includinggastrointestinal tract or genitourinary tract may produce signs that mimic acute abdomen or acute scrotum, and lead to an unnecessary surgical intervention including intussusceptions, perforation, and testicular tortion (6). Torsion of the testis, torsion of the appendix testis, and epididymitis are three major diagnostic categories in the differential diagnosis of acute scrotal pain in children, in descending order (7). For fear of testicular torsion, the patients usually undergo exploration, although most cases have no surgical indications (8). Lee JS et al. reported 7 cases of acute scrotum associated with HSP, 2 of them underwent operation and 5 of them received conservative treatment only (9). In their report, they mentioned that the clinical symptoms of acute scrotum developed on the same day (in 2 cases) or after 1-14 days (in the other 5 cases) of skin rashes but in our case the clinical picture of acute scrotum developed one week before skin rashes and surgical exploration revealed an edematous, hyperemic testis and epydidymis without torsion. Ha et al reported in their study that 26 out of 120 boys $(21.7 \%)$ diagnosed with HSP had scrotal involvement (10). With this case, we don't want to be understood that in such cases surgical procedures can be delayed because torsion of the testis is the single most important condition to rule out and because there may only be a 6- to 12hour period available to save the testis once torsion has occurred (11). So if the findings are inconclusive exploratory scrototomy should not be delayed.

Hardoff et al reported a 4-year old boy presenting with two isolated episodes of tender testicular swelling, who 11 months after the first episode developed a full blown picture of HSP accompanied by orchitis (12). In the literature there are a lot of reports of acute scrotum simultaneously or subsequently to $\operatorname{HSP}(13,14,15)$ but according to our knowledge, except the report by Hardoff et al, there is no case of scrotal swelling mimicking testicular torsion preceding HSP.

In conclusion, this case showed us that an acute scrotum may precede HSP and that vasculitis needs to be included in the differential diagnosis of some surgical conditions such as acute scrotum or acute abdomen.

\section{References}

1. Islek I, Balat A, Cekmen M, Yürekli M, Muslu A, Sahinöz S, Sivasli E. Adrenomedullin and total nitrite levels in children with Henoch-Schönlein purpura. Pediatr Nephrol 2003; 18 (11): 1132-1137.

2. Stewart M, Savage JM, Bell B, McCord B. Long term renal prognosis of Henoch-Schönlein purpura in an unselected childhood population. Eur J Pediatr 1988; 147 (2): 113-115.

3. Farley TA, Gillespie S, Rasoulpour M, Tolentino N, Hadler JL, Hurwitz E. Epidemiology of a cluster of Henoch-Schönlein purpura. Am J Dis Child 1989; 143 (7): 798-803.

4. Cassidy. Acute scrotum - etiology and management.

5. Cavusoglu YH, Karaman A, Karaman I, Erdogan D, Aslan MK, Varlikli O, Cakmak O. Indian J Pediatr 2005; 72 (3): 201-203.

6. Kim CJ, Chung HY, Kim SY, Kim YO, Ryu SY, Kim JC, Chung JH Acute appendicitis in Henoch-Schönlein purpura: a case report. J Korean Med Sci 2005; 20 (5): 899-900.

7. Klin B, Zlotkevich L, Horne T, Efrati Y, Serour F, Lotan G. Epididymitis in childhood: a clinical retrospective study over 5 years. Isr Med Assoc J 2001; 3 (11): 833-835.

8. Huang LH, Yeung CY, Shyur SD, Lee HC, Huang FY, Wang NL. Diagnosis of Henoch-Schönlein purpura by sonography and radionuclear scanning in a child presenting with bilateral acute scrotum. J Microbiol Immunol Infect 2004; 37 (3): 192-195.

9. Lee JS, Choi SK. Acute scrotum in 7 cases of Schoenlein-Henoch syndrome. Yonsei Med J 1998; 39 (1): 73-78.

10. Ha TS, Lee JS. Scrotal involvement in childhood Henoch-Schönlein purpura. Acta Paediatr 2007; 96 (4): 552-555.

11. Chamberlain RS, Greenberg LW. Scrotal involvement in HenochSchönlein purpura: a case report and review of the literature. Pediatr Emerg Care 1992; 8 (4): 213-215.

12. Hardoff D, Jaffe M, Front H. Recurrent episodes of testicular swelling preceding Henoch-Schönlein purpura by 11 months. Eur J Pediatr 1987; 146 (6): 613-614.

13. Søreide K, Ansorge C, Ogreid P. Scrotal pain and Henoch-Schönlein purpura Tidsskr Nor Laegeforen 2004; 124 (3): 335-336.

14. Hara Y, Tajiri T, Matsuura K, Hasegawa A. Acute scrotum caused by Henoch-Schönlein purpura. Int J Urol 2004; 11 (7): 578-580.

15. Dayanir YO, Akdilli A, Karaman CZ, Sönmez F, Karaman G. Epididymoorchitis mimicking testicular torsion in Henoch-Schönlein purpura. Eur Radiol 2001; 11 (11): 2267-2269. 